\title{
Similar to Gods: Some Words in the Imperial Cult in the Roman Empire
}

\author{
Andrés CID ZURITA*
}

\section{Introduction}

When writing the imperial cults, two mayor proposals can be observed about this matter, which have been divulged for almost a century. The first one is a negative appreciation. This considers those manifestations as a manipulation from the central power and superficially religious manifestations. ${ }^{1}$ If this is true, then how and where do we begin to consider the literature of the period and epigraphical evidences? The other appreciation considers the imperial cults as part of the religious system in the Roman World, and the epigraphical records as diverse ways of manifestation to the emperors and the imperial family. ${ }^{2}$

\section{Some Epigraphical Statements}

It is known by the epigraphical records that some emperors refused to be considered as godlike in life or manipulate the imperial cults, trying to avoid a direct link with the honors presented. This illustrates that the imperial cults did not always depend of the princeps. Some examples are: Tiberius refusing divine honors in a letter to the ephors and the city of Gytheum, rejecting any connection with Augustus or the gods and stating '[...] I myself am content with more moderate honors, as befit men'. ${ }^{3}$ This example enlightens that the religious change was not always in the hands of the princeps, but there were others involved in the process, like local elites, politicians in the provinces, and even the underprivileged. ${ }^{4}$ Cassius Dio reminds in his words when Tiberius says in one occasion: 'I am master of the slaves, imperator of the soldiers, and chief of the rest' and Suetonius explained that the new emperor refused some titles like Imperator, Pater Patriae and Augustus. ${ }^{5} \mathrm{~S}$. Mazzarino explains the reason of this rejection: "dalla costante ripugnanza del nuovo imperatore ad ereditare alcune forme decisamente monarchiche dell'ideologia augustea". ${ }^{6}$

* Prof. Dr. Andrés Cid Zurita, MA. in History program, Universidad del Bío-Bío, Chile, Editorial board member of Athenian Periodical of Theory and Praxis, Athens, Greece (andrescidz@gmail.com; https:// orcid.org/0000-0002-1556-3194).

${ }^{1}$ Taylor 1931, 237-238; Nock 1935, 481-503; Nilsson 1948, 177-178; Bowersock 1965, 112-121; Fishwick 1978, 1251-1253; Veyne 1990, 307; Fishwick 2002, 219.

2 Deissmann 1910; Cerfaux - Tondriau 1957; Millar 1977; Hopkins 1978, 197-242; Liebeschuetz 1979; Price 1984a; Price 1984b, 79-95; Friesen 1993; Harland 1996, 319-34; Peppel 2003, 71; Witulski 2007; Lozano 2010, 36-37; De Jong 2016, 22-55.

${ }^{3}$ SEG 11, $922=E^{2} 102 \mathrm{~b}=$ Sherk 1988, 31.

${ }^{4}$ Lozano 2011, 480.

${ }^{5}$ Dio 57.8.2; Suet. Tib. 26.

${ }^{6}$ Mazzarino 2002, 135. 
Claudius tried to keep the traditions by taking two determinations: a) accepting political dedications without direct insinuation of divine attributes, like the statues from the Dionysus' performers in $\mathrm{AD} \mathrm{43,}{ }^{7}$ and one inscription exemplifies the municipal tendencies in the establishment of

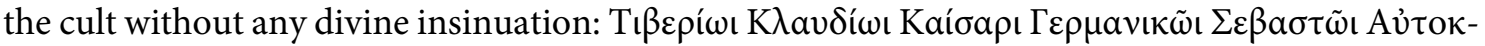


decision against the construction of temples to his person by the people of Alexandria in AD 41: [...] But a priest for me and erection of temples I reject [...] and judging that temples and such things to the gods alone should be reserved and granted by every age, ${ }^{9}$ against the temple from the people of Thasos in AD 42: [...] but I decline the temple because I consider that to be the privilege of the gods alone. ${ }^{10}$ Nero also refused the divine attributes at the beginning of his reign in AD 55: [...] [- - - ] of the remaining two honors your temple I decline because to gods alone is this honor to be granted rightly by men, and the gold crown I released to be sent back to you, not wishing at the beginning of my principate to burden you, ${ }^{11}$ a dying Vespasian exclaimed against the divine condition: Vae, inquit, puto deus fio. ${ }^{12}$ Some members of the imperial family such as Germanicus also reject divine honors: your goodwill [...], I accept, but odious to me are your shouts [...]. They are fitting for the true savior only and the benefactor of the entire race of men, my father and his mother (who is) my grandmother. ${ }^{13}$

Many of the erected inscriptions were unauthorized records, hence the notion must be removed from common sense that the emperor or the imperial family had direct responsibility on those, because the imperatores only tried to put a limit over the private and collective initiatives, but not always achieving that goal. ${ }^{14} \mathrm{~A}$ considered number of individuals put inscriptions across the cities of the Roman World, and even when the emperors did not consent about the erection, there were limited for what they could do. Hadrian on his second visit to the Ephesians was acclaimed as

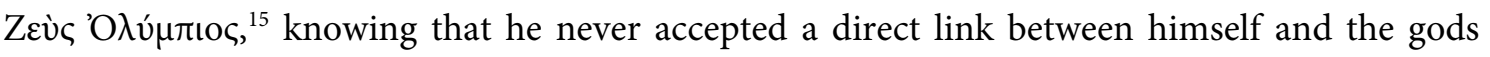
(officially). Vespasian suffered the same destiny: the people from the cities openly created religious manifestations to the princeps, dedicating statue bases with the category of sacred on his honor. ${ }^{16}$ But the cities and the people who honor the emperors and the imperial house go further

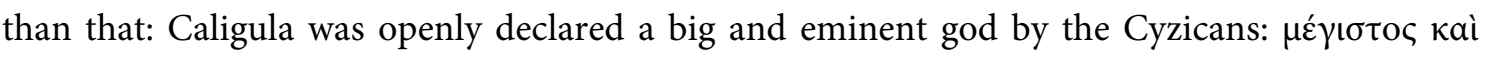


connection with the words of Philo of Alexandria, who wrote that the emperor represented

\footnotetext{
${ }^{7}$ BGU 1074 = SB $5225=$ Smallwood 1967, 373.

${ }^{8}$ I.Cos Segre EV 346b; cf. with few variations in IG 12.4.2: 642.

${ }^{9}$ PLond. 1912 = Sel. Pap. 212 = Smallwood 1967, 370.

${ }^{10}$ Smallwood 1967, 371.

${ }^{11}$ P. Med.inv. 70.01 verso.

${ }^{12}$ Suet. Vesp. 23.4.

${ }^{13}$ Sel. Pap. $211=$ EJ $^{2}$ 320b $=$ Sherk 1988, 34b.

${ }^{14}$ Millar 1977, 387; Beard - North - Price 1998, 352-353; Osgood 2011, 71.

${ }^{15}$ I.Ephesos 4.785 .

${ }^{16}$ MAMA 6.177.

${ }^{17}$ IGR 4.146.
} 
himself superior even to the roman gods. ${ }^{18}$ However, was it the mistake of Caligula or the provincials? Clearly the provinces fed the ego of the emperor.

It is important to recall that the formulas used on the imperial cults do not differ much from honors paid to the gods, ${ }^{19}$ and there were two models for this: one is without cult or divinization and the other attached the divine potentia of the princeps with the gods. ${ }^{20} \mathrm{~J} . \mathrm{H}$. W. G. Liebeschuetz recognized the imperial cult as secular, but also considers that men believed in the survival of the empire "[...] from being sincerely and emotionally involved in it". ${ }^{21}$ This emotion can only be understood if we realize that politics and religion were deeply connected in the ancient world. They cannot be understood as separate processes. ${ }^{22}$ To think that the imperial cults were only political reduces all the academic interpretations and even the religiosity of the ancient world. ${ }^{23}$ Saturninus was very clear in a discussion about the genius of the princeps and the imperial cults when he said: Et nos religiosi sumus, et simplex est religio nostra, et iuramus per genium domini nostri imperatoris, et pro salute eius supplicamus, quod et vos quoque facere debetis. ${ }^{24}$ It is obvious that Saturninus was defending the religious expressions of the Romans, and the public rejection of the Christians was a problem for the continuity and safety of the empire..$^{25}$ The ancients could not understand the politics separate from the religious manifestations. Even A. D. Nock could not reject the idea of religion-imperial cults (= emotions-actions) when he wrote: "There were no doubt moments of intense emotion" ${ }^{26} \mathrm{~A}$ response letter from Caligula expresses the link between politics and religion, considering both as important and emphasizing the religious character of the Greek fashion in direct actions towards the emperor: "I have read the decree given to me [...] and have noted that you have spared no extravagance in your zeal and piety towards me, in that you have each personally offered sacrifice for my welfare and have joined in a common festival and have decreed the greatest honors you could $[\ldots] "{ }^{27}$ This was a moment of intense emotion.

Undoubtedly, the founder of this tradition was Julius Caesar, and Augustus exploited the formulas. Just after the battle of Pharsalus in $48 \mathrm{BC}$, Caesar was called a living god by the Demetrians,

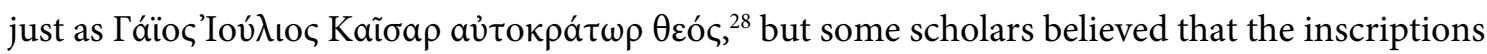
were set up after that date. ${ }^{29} \mathrm{He}$ was also called savior and benefactor of the mankind by the Cart-

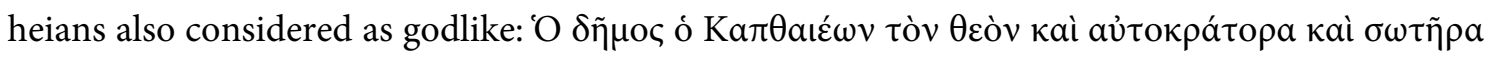

\footnotetext{
${ }^{18}$ Philo Leg. 13.93 .

${ }^{19}$ Peppel 2003, 71.

${ }^{20}$ Harland 1996, 320-321; Lozano 2010, 36-37; cf. Ho 2015, 154; also Amm. 14.6.5-6.

${ }^{21}$ Liebeschuetz 1979, 78.

${ }^{22}$ Hopkins 1978, 200; Price 1984a, 15-16; Beard 1992, 730, 732-734; Friesen 2001, 5-22; Cid Zurita 2012, 2; Winter 2015, 7, 42; Cid Zurita 2018, 71.

${ }^{23}$ Peppard 2011, 33-34.

${ }^{24}$ ASC 3.

${ }^{25}$ Musurillo 1972, 6; in context with the problem: Millar 1973, 145-175.

${ }^{26}$ Nock 1957, 121.

${ }^{27}$ IG 7, 2711 = Smallwood 1967, 361.

${ }^{28}$ SEG $14,474$.

${ }^{29}$ Accame 1946, 174-175.
} 


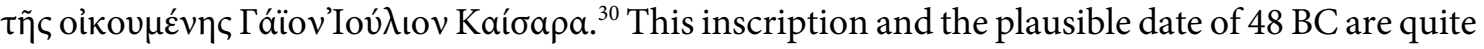
curious because at the same time there was another one from Ephesus and the community of



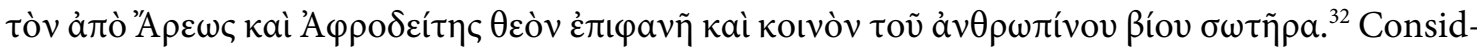
ering this last epigraphical record, it provides information about Caesar's benefactions because

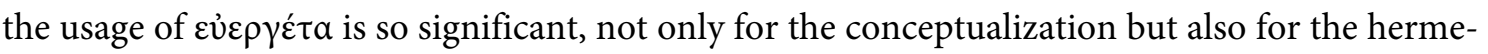
neutical meaning of the dedicators and the readers. ${ }^{33}$ Pergamum expressed their gratitude upon

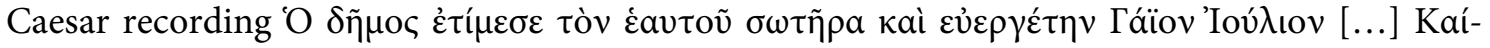
$\sigma \alpha \rho \alpha ;{ }^{34}$ Athens did the same and recognized the saving and benefactor character of Caesar: $[\Gamma]$ áïov

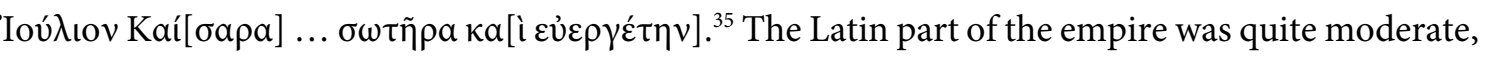
and for this key aspect there are two inscriptions: the first one was settled by legal permission (now is preserved on the Vatican Museums) and they did not call him a god in the Greek style, but divine: Divo Iulio iussu populi Romani statutum est lege Rufrena. ${ }^{36}$ The other inscription talked about the genius of Caesar that was accepted by the Senate and People of Rome and now is held among the Roman gods: Genio deivi Iuli parentis patriae quem senatus populusque Romanus in deorum numerum rettulit. ${ }^{37}$

Julius Caesar's son-in-law was also called god, but his divine relation was officially considered by his birthday and the beginning of good things for the world, just as the Priene inscription records:

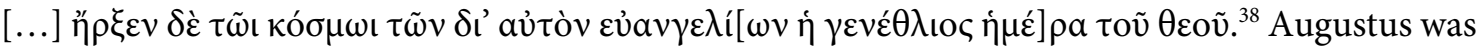
called god, son of god and god of god. These three titles are very important for the statement of this research, because they enclose a significant part of the discussion about the divinity of the Roman emperors. There is no need to believe that these titles were only official because several inscriptions were found of spontaneous initiative. ${ }^{39}$ Someone can be divine yet not necessarily a god in the strict sense of the word, and this is a problem that still arises when the studies of ancient pagan religion try to explore and explain the subject, since the line between man and god on ancient epigraphs is blurry. A useful tool for this problem is the language-game, a world of constructing meanings. ${ }^{40}$ Clearer is the sentence of the academic J. Smith: "what we study when we study religion is one mode of constructing worlds of meaning, world within which men find themselves and in which they choose to dwell". ${ }^{41}$

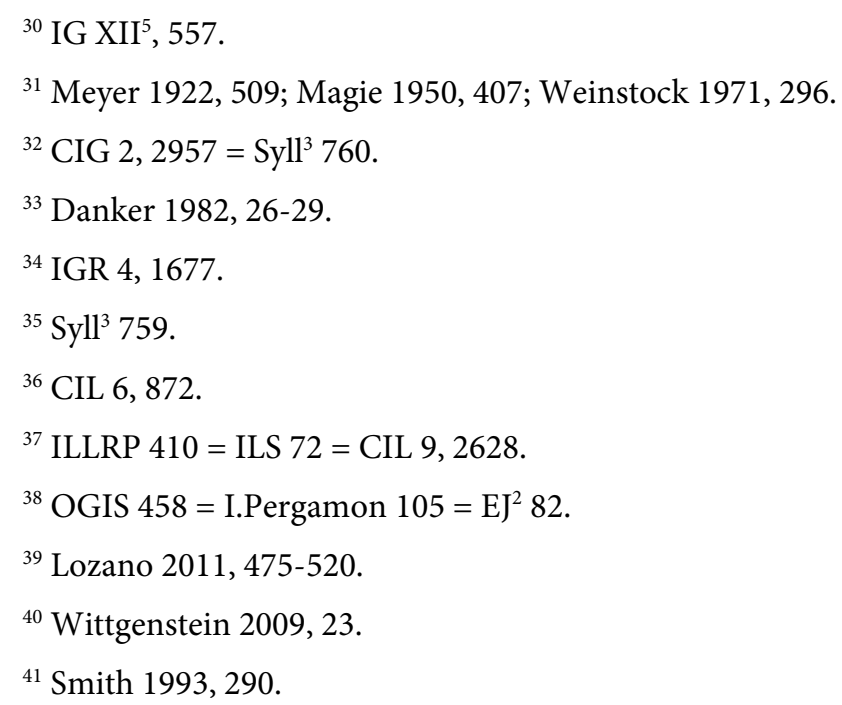


In the imperial cults it must be considered that every action, whether it be a political or social expression, had an inherent religious transmission. ${ }^{42}$ W. S. Ferguson thought that the Hellenistic ruler cult was similar to the Roman ruler cult, and A. Momigliano observed an obvious line for this dilemma: from heroes-cult to Hellenistic rulers, then to the roman magistrates and finally to the roman emperor. ${ }^{43}$ S. Price has denied this theory, considering there was no continuation in


be translated as "honneurs pareils à ceux des dieux", 45 "honours equivalent to those given to the gods", ${ }^{46}$ or "honours equal to those bestowed upon the gods" ${ }^{47}$ Despite of the subtle difference on the translations, there is no need to believe that the emperors were similar to the gods. ${ }^{48} \mathrm{D}$. Fish-

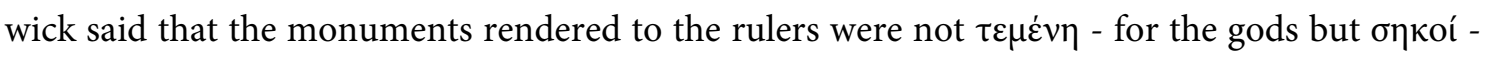
for humans, ${ }^{49}$ and Cassius Dio conveys that in the year 29 BC when the people of Pergamum made the arrangement for a temple for Augustus and Rome, but Dio used the word $\tau \dot{\varepsilon} \mu \varepsilon v o \varsigma$, considering the goddess and not Augustus as the principal deity. ${ }^{50}$ This example evidences the importance of words, the translations and the interpretations. Caesar's death closes a way to understand the ho-

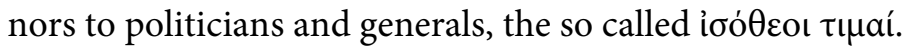

Commonly the title $\theta$ có s was conferred after the death of the individual ${ }^{51}$ but at some point, in history it was bestowed upon the living (see Julius Caesar). Records of this religious title could be

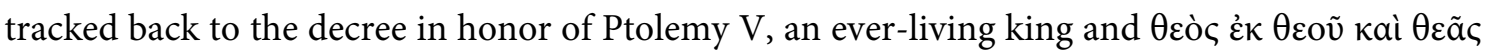

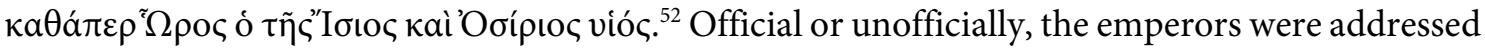
as living gods and as having the power of gods, perhaps for eulogy, recognition, religiosity or just politics like Gordianus - $\Theta \varepsilon$ č ৎ $\Gamma o \rho \delta .,{ }^{53}$ and the title invictus that was understood as an unofficial title years ago, and now the interpretations of official contents in four documents might indicate that it indeed had official status. ${ }^{54}$ Aurelianus was related with the Sol Invictus, keeping the religious sentiment of the period, and some inhabitants believed that, just as the papyrological record in POslo 3.96.1.14 and the POxy 7.1036 who calls the emperor as ávíkntoc. For this point, J. De

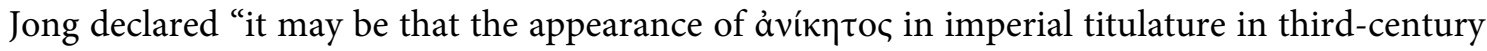
papyrus texts does reflect the perception of Aurelian's imperial representation by at least some

\footnotetext{
${ }^{42}$ Scheid 1985.

${ }^{43}$ Ferguson 1928, 14; Charlesworth 1935, 8-12; Momigliano 1986, 184-186.

${ }^{44}$ Price 1984a, 53; Price 1984b, 23; Millar 1984, 53; Cid Zurita 2013, 8; Cid Zurita 2018, 77. For emperorcult: Herzog-Hauser 1924, 806-853.

${ }^{45}$ Cerfaux - Tondriau 1957, 201.

${ }^{46}$ Price 1984b, 28.

${ }^{47}$ Chaniotis 2003, 433.

${ }^{48}$ Cid Zurita 2018, 73-75.

${ }^{49}$ Fishwick 1993, 21-31.

${ }^{50}$ Dio 51.20.6-8.

${ }^{51}$ Cuss 1974, 24.

${ }^{52}$ OGIS 90.1.10 = CIG 3, $4697=$ SB 8299.

${ }^{53}$ PAnt. 3.191.9; cf. Peachin 1990, group A, 8.18: divi Gordd. in allusion of legal recognition to Gordianus I and II? Gordianus III as a descendent of divinized emperor: TAM 4, 14 - Imp. Caes. divi Gord. nepos.

${ }^{54}$ De Jong 2006, 109; cf. De Jong 2016, 39, n. 60.
} 
inhabitants of Egypt". ${ }^{55}$ And similar it must be for Domitian with the plausible inscription of him,

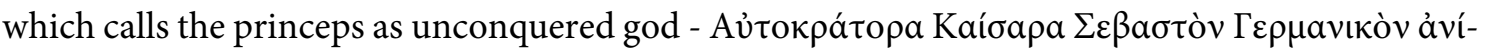

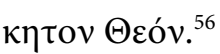

For instances of eulogy and thanksgiving, there are inscriptions like that of the people of Larisa to

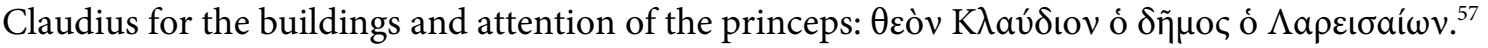
In 30-29 BC, four lamplighters of two temples in Egypt made an oath to Octavian, calling him

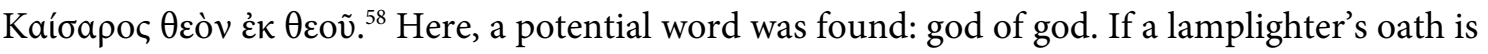
curious, then an oath made by some sheep farmers would be even more curious and significantly less common after reparations and re-erection of the surrounding walls of the temple: They have

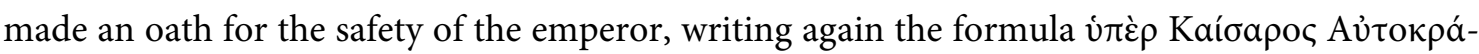

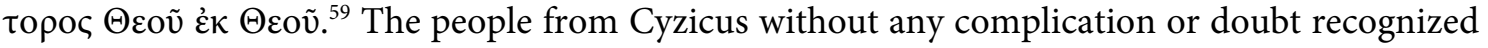

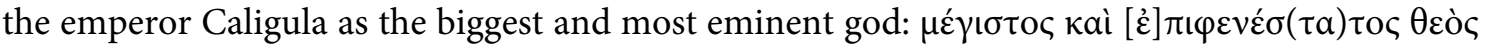
[[Гáïoc]] Kaĩoap. ${ }^{60}$ On the other hand, Claudius was celebrated as god for this birthday at the

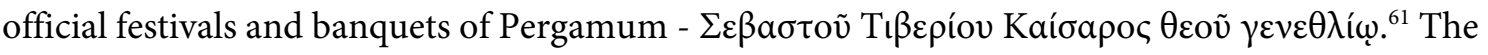
epigraphical records go even further and by the Coan decree. It was declared Augustus as a god and even superior to the Olympian Gods, but not by power, but by his benefactions to all men:

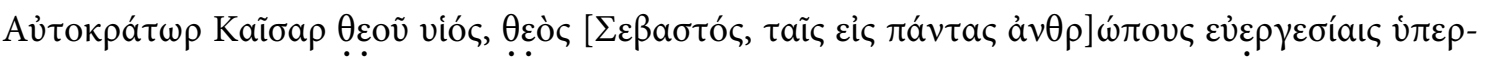


when the people of the polis decreed that Augustus had a heavenly reputation and possessed the power and authority of the gods, and the city would do anything to deify him. ${ }^{63}$ In Pergamum it was declared that Augustus was a god and son of god of every land and sea, and even the overseer

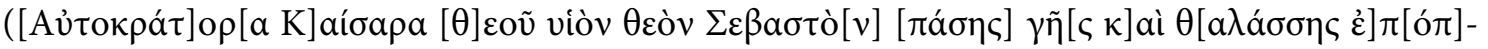
$\tau[\eta \nu]){ }^{64}$ After a century, the name of Augustus will be associated as a title, and sometime later from the time of Marcus Aurelius, someone named Tiberius Claudius Milatos as v $\mu \nu \omega \delta$ ov $\theta \varepsilon o \tilde{v}$

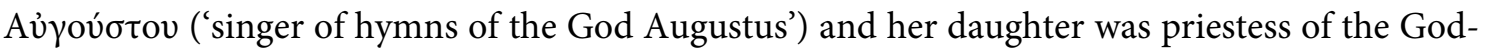

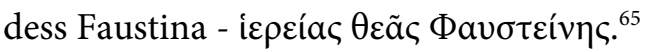

In official titulature, the ruling emperor was associated in some cases with the divinity of the dead

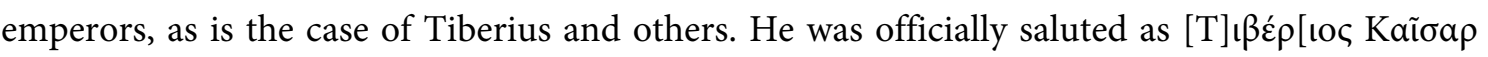

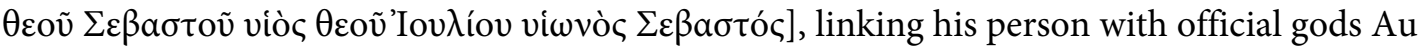

\footnotetext{
${ }^{55}$ De Jong 2006, 110.

${ }^{56}$ SEG 32, 1099.

${ }^{57}$ IG 9.2, 605 .

${ }^{58}$ POxy 12.1453 = Sel. Pap. 2.327.

${ }^{59}$ OGIS 655 = IGR $1.1116=$ SEG 26, 1750.

${ }^{60}$ IGR IV, 146.

${ }^{61}$ I.Ephesos 3801.

${ }^{62}$ I.Olympia 53.

${ }^{63}$ IGR $4.39=$ OGIS 456.

${ }^{64}$ I.Pergamon 381.

${ }^{65}$ I.Pergamon 523.
} 


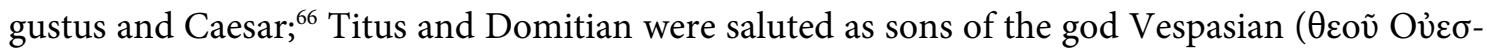

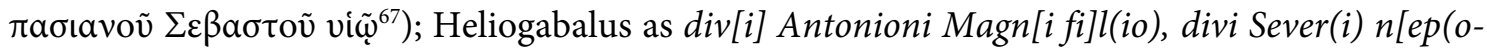

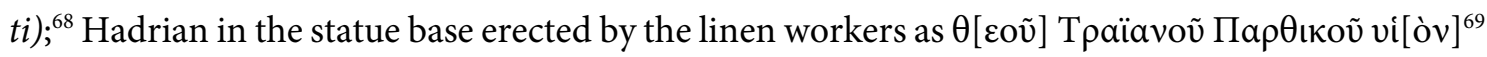
or in the thanksgiving for distributed food among children: [Imp(eratori) Caesari] divi Trai]ani [Parthici] fil(io) [divi Nerv]ae [nepoti] [Traiano Hadr]iano [Aug(usto)[...] [pueri et p]uellae [alimentariae $;^{70}$ Marcus Aurelius was saluted in Samos and linked as heir and grandson of gods:



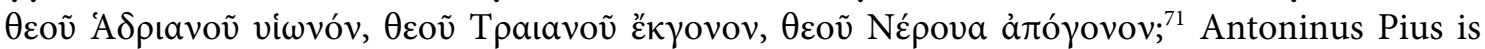
even remembered in a judicial verdict of the titles and divinity of his predecessors: $\theta[\varepsilon 0] \tilde{v}$ A $\delta \rho \iota \alpha-$

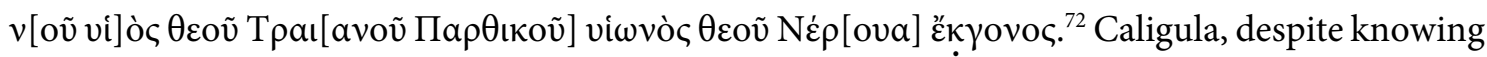
that Tiberius was not considered a god by the Roman estate, tried to associate his principate with

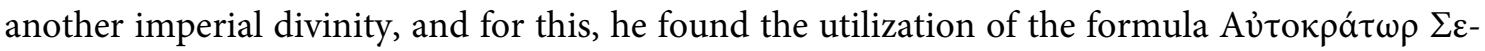

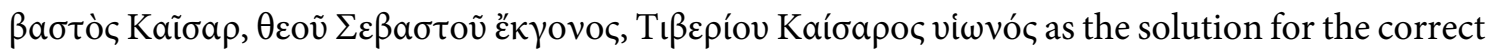
transmission of power. ${ }^{73}$

The title of $\theta \varepsilon$ ć was not the only one bestowed upon the emperors, and there are two peculiar

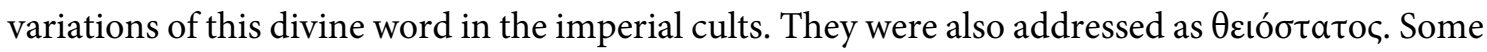
emperors were known for their military capability, such as Septimius Severus who was addressed

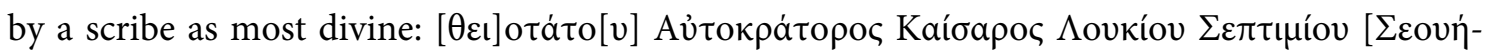

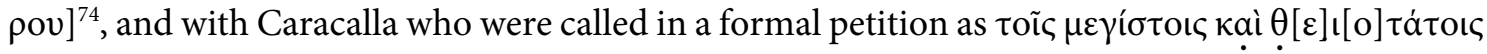

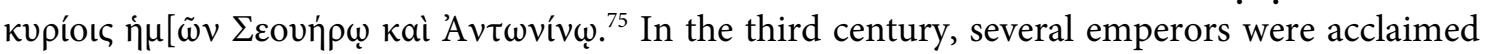


Gordianus was saluted with the same formula ${ }^{77}$ and even as a god. ${ }^{78}$ Phillipus the Senior was ac-

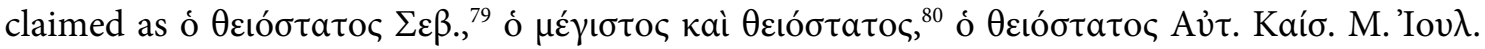

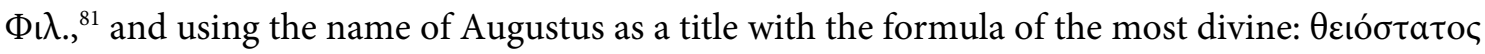

\footnotetext{
${ }^{66}$ SEG 45, 1644.

${ }^{67}$ IGR 4, $1393=$ CIG 3173.

${ }^{68}$ ILTG.221 = AE 1955, 210.

${ }^{69}$ IGR 3, 896.

${ }^{70}$ AE 2009, 207.

${ }^{71}$ IG 12.6.1 no. 421.

${ }^{72}$ POxy 47.3361.

${ }^{73}$ IG 07.2711= Smallwood 1967, 361.

${ }^{74}$ SB 18.13175.

${ }^{75}$ POxy 47.3364.

${ }^{76}$ IG 2.2.3420; IGBulg 1515.

${ }^{77}$ IGBulg 641 and 642; AE 1902, 115.

${ }^{78}$ IGR 3, 235.

${ }^{79}$ IGR 1, 1478.

${ }^{80}$ SEG 28, 1978, 589, 590, 591; IGR 4, 19.

${ }^{81}$ IGR 1, 757.
} 


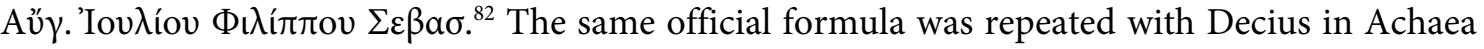
and Thrace. ${ }^{83}$ In Achaea, Gallus was known as the lord of us, the biggest and most divine, embod-

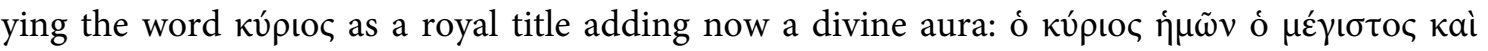

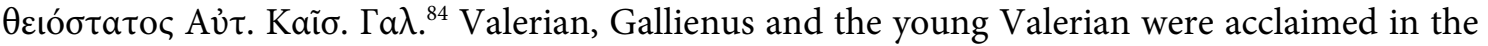

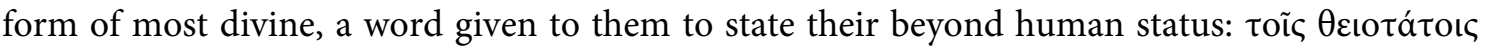

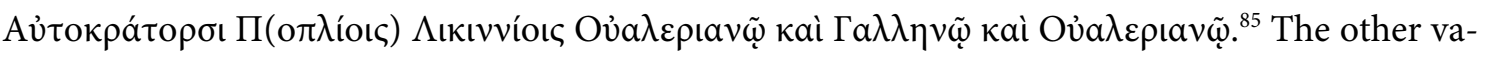
riation is the title $\theta \varepsilon \sigma \varphi \iota \lambda \dot{\varepsilon} \sigma \tau \alpha \tau o \varsigma$ which singularity is important, because it can be translated as 'dearest to the gods' and 'most god-loving'. It is common to find this title after the collapse of the Severan dynasty and it seems that the concept tried to calm the stormy years of anarchy. Gaius Julius Vero, better known as Maximus (AD 235-238), was called on Latin inscription as nobilissimus Caesar, but in the Greek inscriptions is called $\theta \varepsilon \circ \varphi \iota \lambda \dot{\varepsilon} \sigma \tau \alpha \tau o \varsigma$ Kaĩ $\alpha \rho,{ }^{86}$ Hostilianus was ad-

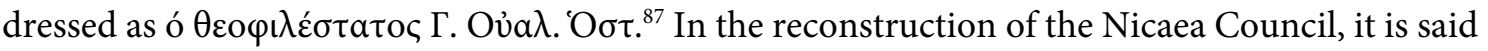



The first princeps open a new form of official and unofficial dedications. Augustus was celebrated in $29 \mathrm{BC}$ by the Senate and the People of Rome as a savior and protector: Imp(eratori) Caesari divi [...] re publica conservata. ${ }^{88}$ Twenty years after that acclamation, Augustus was given a supplication in the Fasti Cumae: Imperio Caesaris Augusti custo[dis $].{ }^{89}$ Certainly, these two inscriptions do not expose any divine attribute in the Latin West, but in the Greek East the story was quite different. The word for this difference is $\sigma \omega \tau \eta \dot{\rho} \rho$. The soteria is understood as a power of safety, protection and many others. In the Greek world, it was understood as a language to express gratitude to the gods or individuals with divine potential "tying the dedicator to the divine in a personal relationship". ${ }^{90}$ The application of this word is not just from the Principate alone. Some utilization of this concept can be established even before the Principate (like when Antiochos -the founder of the Seleucid dynasty- died, it was obviously deified, and also honored as savior: 'Avtío$\chi \circ \varsigma$ 'A ó$\lambda \lambda \omega \nu \Sigma \omega \tau \tilde{\eta} \rho \mathrm{c}[\varsigma]) .{ }^{91}$ It seems like some poleis repeated the same formula when speaking of Julius Caesar since he was also called soter in his lifetime, but not by any official dedications approved by the imperator; for example: in Mytilene IGR 4.57, in Megara IG 7.62, in Athens IG



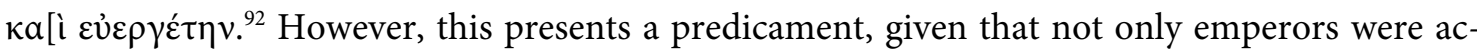
claimed as soter. For example, two politicians were saluted as saviors: Publius Servilius Isauricus

\footnotetext{
${ }^{82}$ AE 1913, 175.

${ }^{83}$ AE 1899, 4; AE 1932, 28.

${ }^{84}$ SEG 11, 122.

${ }^{85}$ IGBulg 2, 834.

${ }^{86}$ IGBulg 638; also AE 1927, 63.

${ }^{87}$ AE 1890, 130 = I.Keramos 33.

${ }^{88}$ CIL 6, 873.

${ }^{89}$ CIL 10, 3682.

${ }^{90}$ Moralee 2004, 3.

${ }^{91}$ CIG 4458.

${ }^{92}$ Syll $^{3} 759$.
} 
in ca $47 \mathrm{BC}$ and Gaius Julius Xenophon in the first century AD. ${ }^{93}$ So the question is: Were Gaius Julius Xenon and Publius Servilius Isauricus divine ones? Not really. And this is because of the nature of the two inscriptions as political dedications. So, A. Harnack was wrong on his interpretation that "a Saviour ( $\sigma \omega \tau \eta \dot{\rho} \rho)$ could only be represented somehow as a Divine being" and I. Ezeani was right when he considered the particularity of soter as a sign of gratitude and used as an official form of recognition..$^{94}$

Hadrian was acclaimed as soter and also as ktistes (a founder), which can be supported by a list of thirty-three inscriptions on altars evidencing this relation between the communities and the emperor. ${ }^{95}$ Even through the historical process known as anarchy, the titulature kept some formulas

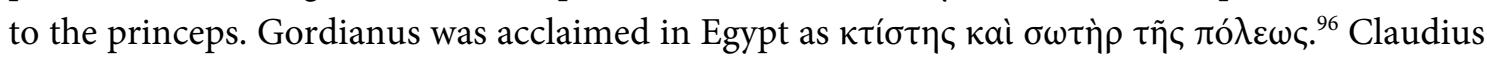
is one of the best examples for this. The attention of the emperor with the empire is even recorded by his own words in the imperial edict of Tegea, trying to relieve of economic problems of not only Italy, but of the provinces as well: cum et colonias et municipia non solum Italiae verum etiam provinciarum item, civitatium cuiusque provinciae lebare oneribus vehiculorum praebendorum saepe temptavissem et cum satis multa remedia invenisse mihi viderer potuit tamen nequitiae hominum non satis per ea occurri. ${ }^{97}$ In Sidyma (Lycia), Quintus Veranius, legatus propretorian of Claudius, erected an inscription to the $\Theta \varepsilon \circ \tilde{c} \varsigma \sigma \omega \tau \tilde{\eta} \rho \sigma \iota \Sigma \varepsilon \beta a \sigma \tau o \tilde{c},{ }^{98}$ bringing special attention to

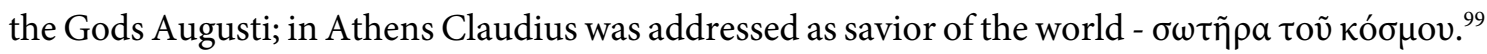


of the emperor across the empire was not physical at all, but through images, temples, altars, dedications, and any form of cultic devotion. That is why it is not strange to find epigraphical records with this usage: Caligula was addressed as the biggest and the most manifested of the gods by a

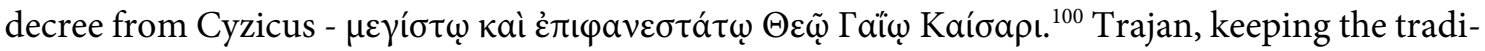

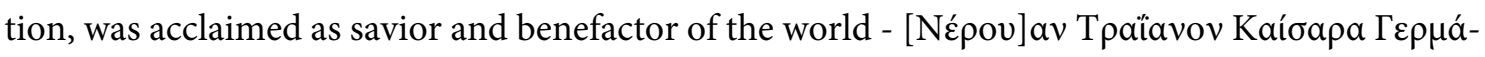

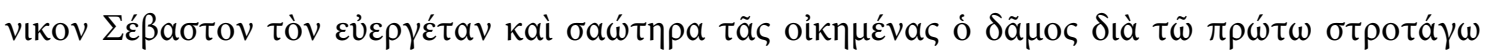

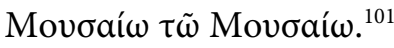

Some emperors were associated with specific gods: Tiberius was acclaimed as Tı $\beta \varepsilon \rho i \omega \iota \mathrm{Ka}\left[i \sigma^{\circ} \rho \mathrm{\iota}\right.$

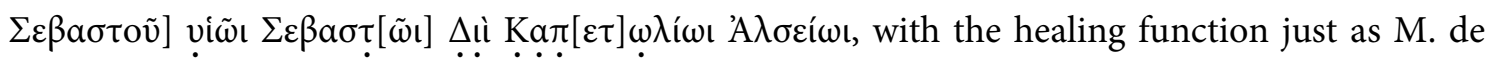
Rossi recalled; ${ }^{102}$ Claudius was assimilated with Poseidon and Asclepios in a Coan round altar as



\footnotetext{
${ }^{93}$ IGR 4, 433; Keil - Premerstein, Lydien II 1098 = IGR 4, 1276.

${ }^{94}$ Harnack 1901, 189; Ezeani 2010, 70.

${ }^{95}$ IG $12.6,503-536$.

96 POxy 50.3593.

${ }^{97}$ ILS $214=$ CIL 3, $7251=$ Smallwood 1967, 375.

${ }^{98}$ IGR 3, 577.

${ }^{99} \mathrm{IG} 2^{2}, 3273$.

${ }^{100}$ IGR 4, 146.

${ }^{101}$ IG 12.2, 544.

${ }^{102}$ I.Cos Segre EV 135; De Rossi 2016, 77.

${ }^{103}$ IG $12.4,417$.
} 
Eleutherios in Alabanda, ${ }^{104}$ Zeus Boulaios, ${ }^{105}$ as Zev̀c ${ }^{\prime} E \lambda \varepsilon v \theta \varepsilon ́ p \operatorname{soc}{ }^{106}$ and in Mytilene too, ${ }^{107}$ and

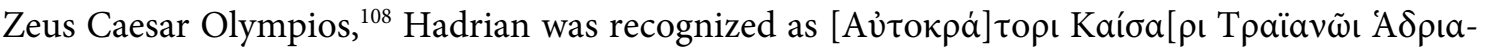

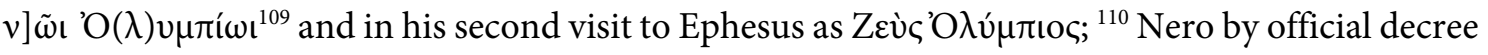
from Acraephia was potentially addressed as lord of the entire world and new Helios kó $\sigma \mu o v$

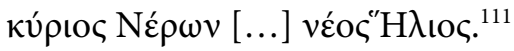

To conclude, a change has to be made. There is information after the battle of the Milvian Bridge in AD 312 which shows that in the city of Cirta in Africa, the priesthood for the gens of Flavia was settled as an attempt to again establish a link the emperor and his family with the tradition of the imperial cults, but Constantine took away all his portraiture from the temples. ${ }^{12}$ When Constantine died, he was divinized. ${ }^{113}$ The Senate of Rome begged for the body but it was all in vain. Now, a new city has the privilege: Constantinople, and with this city comes a new form of funeral. No more apotheosis, the norm now is a Christian burial, and in a Christian church. ${ }^{114}$

\section{Final Considerations}



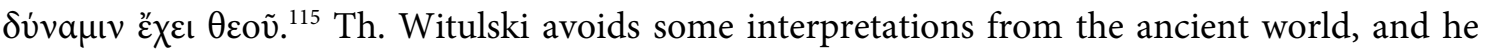
believed that in the Greek context, the subjects worshipped the sovereigns who ruled over them as gods. ${ }^{116}$ Elias Bickerman clearly manifested on a conference that "we should not confuse the divinity and the association with the divine. The monarch by the grace of God, by definition is no deity himself. ${ }^{117}$

Even if the inscription considers the emperor and the imperial as gods, the rulers were not gods in the very sense of the word. The epigraphical records must be seen under a hermeneutical analysis and not literally. Obviously, the rulers and their families were considered special for their position, but to speak openly that they were gods is a misinterpretation. Just as S. Price said: the emperors were something else, and the function of the gods must be understood as power and not as a personification. ${ }^{118}$

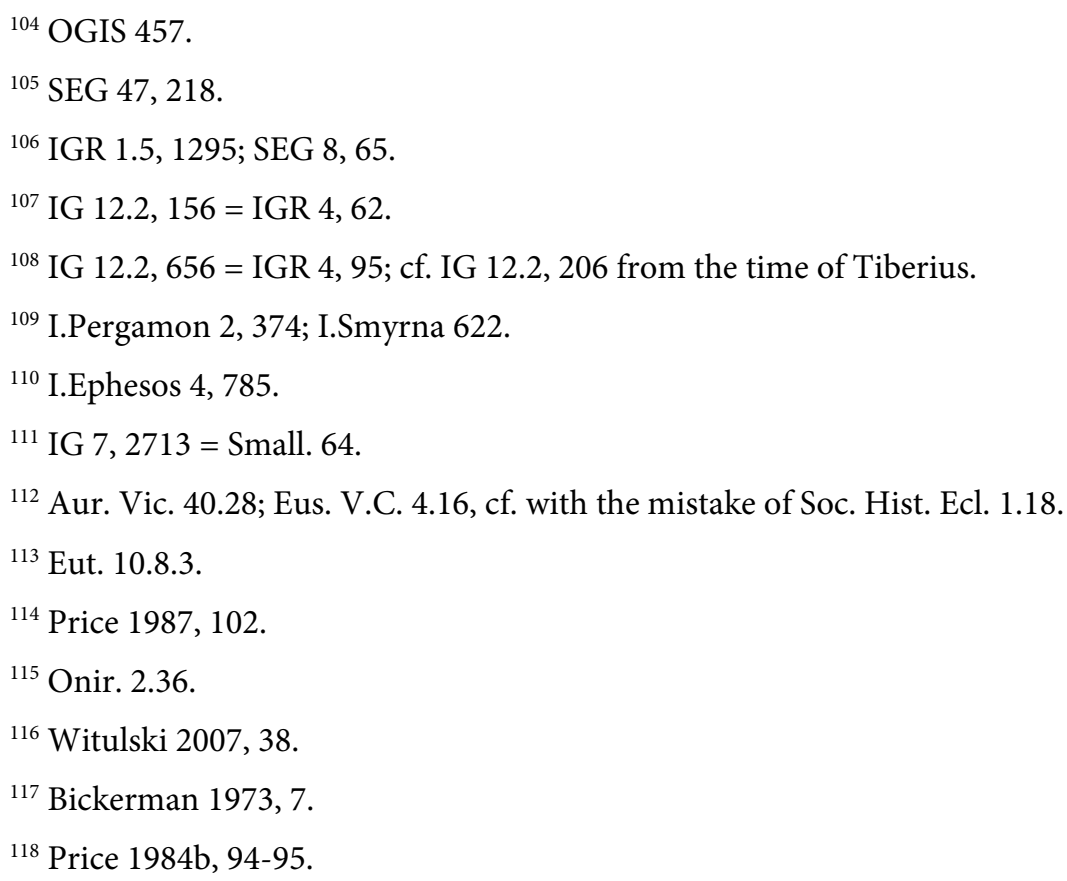




\section{Bibliography}

Accame 1946

S. Accame, II dominio romano in Grecia dalla guerra acaica ad Augusto, Roma 1946.

Beard 1992

M. Beard, Religion, in: J. A. Crook - A. Lintott - E. Rawson (eds.), The Cambridge Ancient History, 2nd ed., vol. 9, Cambridge 1992, 729-768.

Beard - North - Price 1998 M. Beard - J. North - S. Price, Religions of Rome: A History, vol. 1, Cambridge 1998.

BGU Aegyptische Urkunden aus den Königlichen (später: Staatlichen) Museen zu Berlin, Griechische Urkunden I, Berlin 1895 - Bd. XX, 2014.

Bickerman 1973

E. Bickerman, Consecratio, in: W. den Boer (ed.), Le culte des sourverains dans l'empire romain, Genève 1973, 3-37.

Bowersock 1965

G. Bowersock, Augustus and the Greek World, Oxford 1965.

Cerfaux - Tondriau 1957

L. Cerfaux - J. Tondriau, Le culte des souverains dans la civilisation gréco-romaine, Tournai-Paris 1957.

Chaniotis 2003

A. Chaniotis, The Divinity of Hellenistic Rulers, in: A. Erskine (ed.), A Companion to the Hellenistic World, Oxford 2003, 431-445.

Charlesworth 1935

M. P. Charlesworh, Some Observations on Ruler-Cult, Especially in Rome, HTR 28, 1935, 5-44.

Cid Zurita 2012

A. Cid Zurita, La implementación del principado: Política y Religión en el Imperio Romano. 31 a.C.-68 d.C., MA. In History Diss., Universidad de Concepción, Concepción 2012.

Cid Zurita 2013

A. Cid Zurita, The Implementation of the Roman Principate: Between Human and Divine, ATINER'S Conference Paper Series, Athens 2013, 5-16.

Cid Zurita 2018

A. Cid Zurita, Cruzando la frontera: el impacto e incorporación de títulos en la adoración a los emperadores romanos, in: A. Saez Geoffroy (ed.), Límites: Estudios sobre las fronteras en el mundo Grecorromano, Temuco 2018, 69-88.

Cuss 1974

D. Cuss, Imperial Cult and Honorary Terms in the New Testament, Fribourg 1974.

Danker 1982

F. Danker, Benefactor: Epigraphic study of a Graeco-Roman and New Testament Semantic Field, Missouri 1982.

De Jong 2006

J. de Jong, Emperors in Egypt: The Representation and Perception of Roman Imperial Power in Greek Papyrus Texts (PhD. Diss. Universiteit) Nijmegen 2006.

De Jong 2016

J. de Jong, Emperor Meets Gods: Divine Discourse in Greek Papyri from Roman Egypt, in: M. Kahlos (ed.), Emperors and the DivineRome and its Influence, Helsinki 2016, 22-55. 
De Rossi 2016

Deissmann 1910

$E J^{2}$

Ezeani 2010

Ferguson 1928

Fishwick 1978

Fishwick 1993

Fishwick 2002

Friesen 1993

Friesen 2001

Harland 1996

Harnack 1901

Herzog-Hauser 1924

Ho 2015

Hopkins 1978

ILLRP

ILTG

Liebeschuetz 1979
M. I. De Rossi, LE FRONDE DEGLI DEI. Gli alberi nella vita religiosa della Grecia antica: il contributo dell'epigrafia, Tesi di Laurea, Università Ca'Foscari Venezia, Venezia 2016.

A. Deissmann, Light from the Ancient East. The New Testament Illustrated by Recently Discovered Texts of the Graeco-Roman World, London 1910.

A. H. M. Jones - V. Ehrenberg, Documents illustrating the reigns of Augustus and Tiberius, 2nd ed., Oxford 1976.

I. Ezeani, The Apologetic revisited: Exonerating Luke from an Ancestral Exegetical and Theological Burden, Inaugural Dissertation zur Erlangung des akademischen Grades eines Doktors der Theologie, Würzurg 2010.

W. S. Ferguson, The Leading Ideas of the New World, in: S. A. Cook - F. E. Adcock - M. P. Charlesworth (edd.), The Cambridge Ancient History, 1st ed., vol. 7, Cambridge 1928, 1-40.

D. Fishwick, The Development of Provincial Ruler Worship in the Western Roman Empire, in: W. Haase (ed.), Aufstieg und Niedergang der römischen Welt, vol. 2, 16, 2, Berlin-New York 1978, 12011253.

D. Fishwick, The Imperial Cult in the Latin West, vol. 2, part 1, Leiden 1993.

D. Fishwick, The Imperial Cult in the Latin West, vol. 3, part 1, Leiden 2002.

S. Friesen, Twice Neokoros: Ephesus, Asia, and the cult of the Flavian Imperial Family, Leiden-New York 1993.

S. Friesen, Imperial cults and the Apocalypse of John: reading Revelation in the ruins, New York 2001.

P. Harland, Honours and worship: Emperors, imperial cults and associations at Ephesus (first to third centuries C.E.), SR 25/3, 1996, 319-334.

A. Harnack, History of Dogma, vol. 1. Boston 1901.

G. Herzog-Hauser, Kaiserkult, RE IV, 1924, 806-853.

S. D. Ho, Paul and the Creation of a Counter-Cultural Community: A Rhetorical Analysis of 1 Cor. 5.1-11.1 in Light of the Social Lives of the Corinthians, London 2015.

K. Hopkins, Conquerors and Slaves, vol. 1, Cambridge 1978.

A. Degrassi, Inscriptiones Latinae liberae rei publicae, GöttingenFirenze-Berlin 1957-1965.

P. Wuilleumier, Inscription latines des trois Gaules, Paris 1963.

J. H. W. G. Liebeschuetz, Continuity and change in Roman religion, Oxford 1979. 
Lozano 2010

Lozano 2011

Magie 1950

Mazzarino 2002

Meyer 1922

Millar 1973

Millar 1977

Millar 1984

Momigliano 1986

Moralee 2004

Musurillo 1972

Nilsson 1948

Nock 1935

Nock 1957

Osgood 2011

PAnt

Peachin 1990

Peppard 2011

Peppel 2003
F. Lozano, Un dios entre los hombres: la adoración a los emperadores romanos en Grecia, Barcelona 2010.

F. Lozano, The Creation of Imperial Gods: Not only Imposition versus Spontaneity, in: P. Iossif - A. Chankowski - C. Lorber (eds.), More than Men, Less than Gods, Leuven-Paris: Peeters 2011, 475520 .

D. Magie, Roman Rule in Asia Minor: to the end of the third century after Christ, vol. 1: text, New Yersey 1950.

S. Mazzarino, L'Impero Romano, vol. 1, Roma 2002.

E. Meyer, Caesars Monarchie und das Principat des Pompejus: Innere Geschichte Roms von 66 bis 44 v. Chr., Stuttgard-Berlin 1922.

F. Millar, The Imperial Cult and the Persecutions, in: W. den Boer (ed.), Le culte des sourverains dans l'empire romain, Genève 1973, 145-175.

F. Millar, The Emperor in the Roman World (31 BC-AD 337), London 1977.

F. Millar, State and Subject: The Impact of Monarchy, in: F. Millar E. Segal (eds.), Caesar Augustus: seven aspects, Oxford 1984, 37-60.

A. Momigliano, How Roman Emperors Became Gods, ASch 55/2, 1986, 184-86.

J. Moralee, "For salvation's sake": provincial loyalty, personal religion, and epigraphic production in the Roman and late antique Near East, New York-London 2004.

H. Musurillo, The Acts of the Christian Martyrs, Oxford 1972.

M. P. Nilsson, Greek Piety, Oxford 1948.

A. D. Nock, Religious Developments from the Close of the Republic to the Death of Nero, in: S. A. Cook - F. E. Adcock - M. P. Charlesworth (edd.), The Cambridge Ancient History, 1st ed., vol. 10, Cambridge 1935, 481-503.

A. D. Nock, Deification and Julian, JRS 47, 1957, 115-123.

J. Osgood, Claudius Caesar: Image and Power in the Early Roman Empire, Cambridge 2011.

J. W. B. Barns - H. Zilliacus, The Antinoopolis Papyri, vol. 3, London 1967.

M. Peachin, Roman Imperial Titulature and Chronology, A.D. 235284, Amsterdam 1990.

M. Peppard, The Son of God in the Roman World: Divine Sonship in its Social and Political Context, New York 2011.

M. Peppel, Gott oder Mensch? Kaiserverehrung und Herrschaftskontrolle, in: H. Cancik - K. Hitzl (edd.), Die Praxis der Herrscherverehrung in Rom und seinen Provinzen, Tübingen 2003, 69-95. 
PLond

POxy

Price 1984a

Price 1984b

Price 1987

Samos

SB

Scheid 1985

Sel. Pap.

Sherk 1988

Smallwood 1967

Smith 1993

Taylor 1931

Veyne 1990

Weinstock 1971

Winter 2015

Wittgenstein 2009

Witulski 2007
Greek Papyri in the British Museum, London 1893-1974.

The Oxyrhynchus Papyri, London 1898-2010.

S. Price, Rituals and Power. The Roman Imperial Cult in Asia Minor, Cambridge 1984.

S. Price, Gods and Emperors: The Greek Language of the Roman Imperial Cult, JHS 104, 1984, 79-95.

S. Price, From noble funerals to divine cult: the consecration of Roman Emperors, in: D. Cannadine - S. Price (eds.), Rituals of Royalty: power and ceremonial in traditional societies, Cambridge 1987, 56 105.

D. McCabe, Samos Inscriptions. Texts and List. «The Princeton Project on the Inscriptions of Anatolia», The Institute for Advanced Study, Princeton 1986.

Sammelbuch griechischer Urkunden Aegypten. (I: F. Preisigke, Estrasburgo-Berlín 1913-15 [dG 1974] (n. 1-6000).

J. Scheid, Religion et piété à Rome, Paris 1985.

A. Hunt - C. Edgar, Select Papyri, vol 2, Non Literary Papyri and Public Documents (Loeb Classical Library), London 1963.

R. Sherk, Translated Documents of Greece and Rome. VI. The Roman Empire: Augustus to Hadrian, Cambridge 1988.

E. Mary Smallwood, Documents illustrating the Principates of Gaius, Claudius and Nero, Cambridge 1967.

J. Smith, Map is not territory: Studies in the History of Religion, Chicago 1993.

L. R. Taylor. The Divinity of the Roman Emperor, Philadelphia 1931.

P. Veyne, Bread and Circuses, London 1990.

S. Weinstock, Divus Iulius, Oxford 1971.

B. Winter, Divine Honours for the Caesars: The First Cristians' Responses, Michigan 2015.

L. Wittgenstein, Philosophical Investigations, Singapore 2009.

Th. Witulski, Kaiserkult in Kleinasien. Die Entwicklung der kultisch -religiösen Kaiserverehrung in der römischen Provinz Asia von Augustus bis Antoninus Pius, Fribourg 2007. 


\section{Tanrılar Gibi: Roma İmparatorluğu'nda İmparator Kültündeki Bazı İfadeler Öz}

Augustus öldügünde imparatorluk kültleri tüm Akdeniz'de yaygınlaşmıştı. Buna istinaden, princeps ve imparatorluk ailesine yönelik tanrısal ve tanrılaştıran sözcüklerin nasıl üretildiğini ve eğer bu ifadelerin (günlük yaşamda bile) tanrısallığın samimi bir şekilde dile getirilmesi ya da yaranma olup olmadığını hatırlamak önemlidir. Seçilmiş bazı Yunanca ve Latince yazıtların yorumlanması yoluyla, bu çalışma çeşitli zıt öğeler sunmayı ve imparatorluk kültleri konseptine yeni öneriler getirmeyi hedeflemektedir. Zira bu dini dişavurum sadece devamlılık ve eklemelerle giden bir kült formu değildi. Aslında veriler, diğer yönetici kült formlarıyla karşılaştırıldığında bazı farklılıklar göstermektedir. İfadelerin önemi üniktir: bir kişinin ya da çeşitli bireylerin ifade edilmesini olduğu gibi ya da mecazi olarak gösterebilmektedirler. Yazıtların bireylerin retoriğini abartabileceğini ve L. Wittgenstein'in işaret ettiği üzere, "dil oyunu” nun yok sayılamayacağına dikkat etmek önemlidir.

Ayrıca, coğrafi yerler ve kültürel dışavurumlar nedeniyle imparatorluk kült ifadeleri değişebileceğinden bunları dikkate almak önem arzetmektedir. Makalede, dini ve politik içerikteki epigrafik veriler ve edebi metinler çerçevesinde, imparatorluk kültü titulatürü ve hali hazırda devam sorunlar hakkındaki bazı düşünceler gözlemlenebilir.

Anahtar Sözcükler: İmparatorluk kültleri, Roma imparatorlarının tanrısallıkları, Eski Yunanca Yazıtlar, Latince Yazıtlar.

\section{Similar to Gods: Some Words in the Imperial Cult in the Roman Empire}

\section{Abstract}

When Augustus died, the imperial cults were widely spread all over the Mediterranean. Considering that, it is important to recall how the divine and divinizing words were produced for the princeps and the imperial family, and, if these words can be seen as a sincere expression of divinity (even in life) or just as a form of adulation. Through the interpretation of a few selected Greek and Latin inscriptions, the following study seeks to establish various contrasting elements and to put forward new suggestions to the concept of imperial cults, since this religious manifestation was not the only form of cult with continuations and additions. In fact, evidence has shown a number differences when compared to other ruler-cult forms. The importance of words is unique: they are able to literally and figuratively show the expression of a person or several individuals. It is important to note that inscriptions can exaggerate the individuals' rhetoric and that "the language-game" cannot be forgotten, as L. Wittgenstein pointed out.

Furthermore, the geographical locations and the cultural manifestations are important to consider as the imperial cult words may vary because of it. By using the religious and political epigraphical monuments and the literature of the period, some ideas can be tracked about the titulature of the imperial cult and the problems that still arise.

Keywords: Imperial Cults, Divinity of Roman Emperors, Greek Inscriptions, Latin Inscriptions. 